\title{
CIVILIZATION, GLOBALIZATION AND THE DIFFERENCES THAT MAKE THE DIFFERENCE. IN HONOR AND MEMORY OF JOHAN "JOOP" GOUDSBLOM
}

\author{
Andrea Pitasi $^{1}$ \\ ${ }^{1}$ University of Gabriele D'Annunzio, Pescara, Italy \\ * Correspondent author: Andrea Pitasi - pitasigda@gmail.com \\ Received: 10. May 2020; Accepted: 2. June 2020; Published: 18 September 2020 \\ DOI: https://doi.org/10.46473/WCSAJ27240606/18-09-2020-0015 \\ Category: Reflection paper \\ You should never start with experts because if you are completely ignorant, you have nothing \\ to offer, and they will not be interested in dialogue. So you have to familiarize yourself with \\ the object and think about it, so that the experts will take you seriously and may also be \\ interested in your ideas". \\ J. Goudsblom (in Goudsblom-Pitasi, 1996:123) \\ http://norbert-elias.com/joop_goudsblom/
}

\begin{abstract}
The death of Johan Goudsblom (1932-2020), as happens to great scholars at their passing, in addition to the pain for both human and intellectual loss, brings with it the important and complex challenge of his remarkable scientific legacy and how to enhance it by making it fruitful for the greatest number of scholars, students, policy modelers, entrepreneurs, professionals and citizens with a curious and lively intellect all over the world. Therefore, obviously, some biographical references will be made, we will briefly talk about the sociological (and historical) tradition in which his thought and works are inscribed, but we will avoid any boring didactic-philological approach that usually tends to freeze the inheritance into something arid, while the message of "Joop" is very much alive, dynamic and vital. Thus, this essay, in its own small way, will try to give it further energy by proposing a line of research and training that is to a large extent unorthodox, but at the same time is clearly indebted to "Joop" and "The School of Amsterdam". This paper provides a process liking among Goudsblom's biography, thought ad works and, as every legacy or heritage, it evolves towards new challenghes and opportunities that maybe Goudsblom himself did not consider; namely, setting a link between the Eliasian sociology of Process and the Luhmanian complex system theory, which is an open horizon for advanced, policy-focused, social science research .
\end{abstract}

Keywords: globalization, civilization, Goudsblom, process, figuration. 
WORLD COMPLEXITY SCIENCE ACADEMY JOURNAL| Vol. 1 Issue 2, 15 | Fall 2020

\section{Introduction}

The death of Johan Goudsblom (1932-2020), as happens to great scholars at their passing, in addition to the pain for both human and intellectual loss, brings with it the important and complex challenge of his remarkable scientific legacy and how to enhance it by making it fruitful for the greatest number of scholars, students, policy modelers, entrepreneurs, professionals and citizens with a curious and lively intellect all over the world. Therefore, obviously, some biographical references will be made, we will briefly talk about the sociological (and historical) tradition in which his thought and works are inscribed, but we will avoid any boring didactic-philological approach that usually tends to freeze the inheritance into something arid while the message of "Joop" is very much alive, dynamic and vital and this essay, in its own small way, will try to give it further energy by proposing a line of research and training that is to a large extent unorthodox but at the same time is clearly indebted to "Joop" and "The School of Amsterdam" (Antonini, 2018) where I had the honor to be Visiting Research Fellow for a semester in a.a. 1994-95 precisely at the Amsterdam School for Social Science Research (ASSSR) with Abram De Swaan as coordinator and Johan Goudsblom as tutor. Perhaps because I am quite tall and decidedly robust, Professor Goudsblom immediately seemed to me to be a very powerful mind in a rather slender body, albeit of a certain stature, with a clear, crystalline voice but which seemed to come from afar as if that slender body were a medium not powerful enough to give it vigour, as if his mind and his body were going at very different speeds and his voice was trying to give speed in the world to that mind. I remember him very generously, despite the clichés about the Dutch, and I remember him well when I left his studio with a stack of volumes, many of his own, which he had gifted me. A great gesture made with the usual meekness and distance, almost metaphysical. If I called myself his pupil I would be a braggart, but that relationship took various forms over a period of little more than three decades, beginning with "Good morning Professor Goudsblom"... "Hello Andrea" and ending with "Hello Andrea! " and "Hello Joop! " on the waterfront in Pescara in 2011. He was 79 years old and made me understand with affection and empathy, but also with that discretion that all Nordic shame, who would retire to private life (he had already retired academically several years before), that he wanted to go and live a little outside Amsterdam, devote himself to painting and to write his autobiography. Years later, in 2017, I was on the Spui where it intersects with the Kalverstraat, a quiet and nice small corner with cafés and bookshops. In a bookshop window, I saw the hadcover of Joop's autobiography. An already beautifully graphic book cover that seemed to have been conceived by van Gogh with a refined formal photographic portrait of the author, if I remember correctly, in black and white on the back cover. I bought three or four copies, in the first edition, one for me, the others as gifts for friends who could appreciate it. And in the meantime I kept thinking about how to structurally couple sociology of processes and sociology of complex systems. Ever since I had read Nihilism and Culture in 1985, and thirty-two years later, when I saw Joop's biography in the window, I had the feeling that an important circle was about to close. A few hours later, I had an appointment with Abram De Swaan (for a couple of years before, for me confidentially Bram) for a hot chocolate and to 
talk to him about his possible candidacy for the World Complexity Science Academy (WCSA) Medal, for career. As President of WCSA, I had the honor to present him with the award at the 8th WCSA conference that took place at the Europarliament in November of the following year, where I was able to formalize in the WCSA agenda the epistemological - theoretical research strand that is at the heart of my strategic investment plan for my small part of Joop's legacy. In that same conference the WCSA Lifetime Achievement Award was also awarded to Paolo De Nardis for his contribution to the refutation of old systemic sociology and for his contribution to macro-sociology on World Order Policy Modeling.

I had already discovered and read "Nihilism and Culture" as a high school student, one of the two sociology books I read as a high school student (the other is irrelevant here) but I arrived in Amsterdam in 1994 following De Swaan'as works, not Goudsblom, but when I found it in front of me for the first time I immediately connected that surname (which, properly pronounced in Dutch, sounds like a radio wave disturbance to an Italian ear) to that cover and the emotion for me was not little. The strange turns life takes.

\section{A Synthetic Intellectual Biography}

One of the favourite pupils, together with Abram De Swaan, of the great Norbet Elias founder of the Amsterdam School and also at the height of his maturity, Goudsblom never ceased to consider himself a pupil and a continuer of Elias' work, enriching and expanding it with new applications with respect to the voluminous Elias' work, but Goudsblom always rejected the idea that his work could be an overcoming and therefore an archiving of the master's work, indeed he always tried to carry on the link between figuration and (process of) civilization in a strictly Elias' sense (Goudsblom- Pitasi, 1996: 117-128, Tabboni, 1993: 269-271). Goudsblom was and is, in terms of intellectual legacy, a sociologist of processes, an undisputed master of comparative sociology (M. Sasaki- J. A. Goldstone-E. Zimmermann- S.K. Sandelson, 2014: 631-633), a careful culturological analyst of the various Zeitgaeste that his biography placed before him as in understanding and arguing a paradox typical of the 80s: nihilism not as a negation of culture but nihilism as a cultural and social phenomenon among countless others (Goudsblom, 1982) also inscribed among the many forms through the process of civilization tries to take control as much as possible even on the most blind evolutionary forms such as fire (Goudsblom, 1992). Obviously, these few lines have more the function of intriguing, approaching the work of Goudsblom and an authentic intellectual biography would require at least a whole volume. Here instead I will try in an unorthodox way, to treasure his intellectual legacy starting from a statement that would certainly have made Goudsblom's (not much) hair stand out, given the well-known points of contrast between Elias and Parsons (this is an author that in my opinion and not only mine, has caused a lot of damage to sociology, especially two: 1. trying to make absolute a contingency that is to believe that the AGIL scheme with which he described the USA of the Second World War could be the "social system tout court", see De Nardis, 1988 and the 2. other damage is: having politically defeated Sorokin in Harvardian academic struggles without ever even remotely approaching him as a scientific level and 
WORLD COMPLEXITY SCIENCE ACADEMY JOURNAL| Vol. 1 Issue 2, 15 | Fall 2020

therefore imposing the banal AGIL scheme more politically than scientifically, see Pitasi, 2018).

\section{Investments from an inheritance}

From this paragraph begins the presentation of my investment strategy of Goudsblom's inheritance knowing full well, also from the Simmel Philosophy of Money (Simmel, 1978) that the heirs make their own investment plan with the capital, in this case intellectual, received and that that investment plan does not necessarily reflect, indeed very rarely happens, how the "De cuius" would have invested if it were still alive. If we start from the Elias-Parsons relationship (Bortolini, 2005) sociology of processes and systemic sociology could not be further away. I like to remember that Matteo Bortolini, friend of mine before colleague, came to visit me at that time in Amsterdam: I was submerged by an increasingly voluminous and complex doctoral dissertation to be delivered on my return from my Visiting and he had just entered my doctorate. In those days I had an appointment with Goudsblom to interview him about his book on fire (Goudsblom-Pitasi,1996). Little institutionally, I brought Matteo with me and Goudsblom smiled welcomingly at both of us. The interview took place in English and Matteo translated it into Italian, obviously his name was included as translator and, quite unconsciously, but to this day I consider it an honor and a pleasure, I had made him debut in the world of publications, an honor and a pleasure even if he still takes Parsons seriously (Bortolini, 2005), but beyond me, a beautiful gesture of opening of Professor Goudsblom towards, at that time, a very young and unknown scholar that Professor Bortolini still remembers with affection, gratitude and sympathy. AGIL, perhaps, was less rigid and specific than Elias considered him, but he was much less dynamic and universalized than Parsons (De Nardis, 1988 Pitasi, 2018). Elias's criticisms, however, were not the edge that would sink Parsons' systemic sociology. Instead, it would have come from another systemic sociologist who had somehow been Parsons' direct interlocutor: Niklas Luhmann whose essay "Warum AGIL? "("Why AGIL?" Luhmann, 1993) was precisely the final broadside. The crux was that, both synchronously and diachronically, a system does not have a homogeneous function, as was implicit in AGIL: 1 school, family, peer group, church and mass media is completely unlikely that, synchronically, they will transmit the same identical values and the same model of life to the child who will find him/herself, sooner or later, more sooner or later, managing heterogeneous values, lifestyles, a first look at the complexity of the world, of life tout court. 2 Assuming and not allowing this to happen synchronously (but it is completely unlikely), tempus fugit and, diachronically, the world changes, scenarios change and what we learned as a child tends to prove to a large extent and in a relatively short time, obsolete. A person born in the USSR in 1970, for example, would have had a Marxist-Leninist education from elementary school to high school, but then he or she would have had to go to the end of high school/university, having to throw in the dustbin of history this education in conjunction with Perestroijka and the subsequent developments of the Russian Confederation. "Warum AGIL?" thus shows that the social system has no "glue" called "culture", there is no single social system and the AGIL scheme had only sketched out a hypothetical type of social system which is completely specific and contingent, i.e. outdated 
and falsified, at least, by the evolution of the 1989 scenarios. Elias would not have been able to pull such a broadside at Parsons because for the sociology of the processes culture, civilization and civilization process are interconnected even though the Eliasian concept of culture is much more fluid, dynamic and complex than the Parsonsian one as evidenced by the very idea of civilization process. But Goudsblom (1932-2020) and Luhmann (1927-1998), roughly the same age, were not Elias (1897-1990) and Parsons (1902-1979), in turn more or less the same age, Goudsblom and Luhmann also found themselves having to invest their respective inheritances.

\section{Goudsblom and Luhmann}

I arrived in Amsterdam while I was a PhD student in Sociology and Social Policy and my Dutch semester was part of the doctoral program at the University of Bologna. Since I was a freshman in Political Science at the same university, Luhmann had been a pillar of all the most important courses: loved, admired, harshly criticized, harshly judged on a moral level, but nevertheless considered by all the greatest sociologists of Bologna (Ardigò, Donati and Piazzi) an author with whom it was essential to compare in order to really make sociological theory. Obviously, I had also studied Elias but I knew him less than Parsons and Luhmann. This was the look with which I began to observe the intellectual life of the ASSSR and in particular the research groups of Abram De Swaan and Johan Goudsblom. Obviously here I focus on Goudsblom's. One Luhmannian concept that I was well aware of in theory was that of the differences that make the difference. I don't know how much Luhmann and Goudsblom knew each other and I don't want to make exegetical or hermeneutical forcing, but Goudsblom himself gave me the most practical example of the Luhmannian concept mentioned above: he was planning a master's degree in history (and sociology), in twelve lectures from the appearance of unicellular life on earth to Prestroijka. The history of the Elisians is not the history of historians. The Eliasians are not lost in petty quibbles and insignificant details. The Book on Fire (from prehistoric times to the late 1980s of the 20th century) would have been the reference text for one of the twelve lectures, each one as wide-ranging as the one on fire. At the same time, however, I had in mind that the sociologies that are not lost in trivial quibbles are the macro sociologies (Sorokin and Luhmann the two giants on the subject with also important Durkheimian contributions) instead there I realized that the sociology of processes was not lost in trivial quibbles and insignificant details, but it was not a strictly macro sociology and, rather, it saw in its process four distinct and interconnected phases A) psychosocial B) micro C) meso D) macro (Elias, 1988 whose most recent revised application is in De Swaan, 2015) applied to the same phenomenon of global impact (as we would say today) as fire. All this without frills or baroqueisms. The twenty-six-year-old doctoral student, who I was at the time, wondered how to filter the fourphase Elias process through the system/environment paradigm of Luhmann. In hindsight, I should have written an essay on sociological epistemology which I never wrote, however, but this theme went through many of my later writings in a subterranean way and I do not dwell on them. The issue of sociological epistemology mentioned above found as my contingent solution the axiom that everything that makes a difference reaches a macro impact but its operational form may not be macro, I propose an example. A flesh and blood individual named Karl R. 
Popper taught epistemology at the LSE and never disdained even sociological theory and in this field his most important volume was "The open society and its enemies" (Popper, 2012). I am talking about Popper and his legacy as an example of Elias'processuality, so here I am not interested in whether Popper's vision was right or wrong, right or left, liberal or social, etc., I am rather interested in his Elias' processual evolution. Popper is an individual with his psychosocial context made also of his colleagues and students more related to him within a micro context the LSE and London where he is in turn within a meso scenario, the United Kingdom with its academic policies that facilitate/hinder the access and visibility of Popper's work at the macro level which is then the one where an academic school reaches its maximum firepower. The four levels sometimes interconnect in a recursive form. At a certain point, in the psycho-social context of the Popperian classroom, a Hungarian student appeared to whom Popper, more or less consciously and intentionally, will change his life. Today that student (about the same age as Goudsblom and Luhmann), has founded a financial empire considering the speculative bubbles as forms of Popperian falsification, "crash test" to assess how healthy and strong is a national economy, a company or a scholarship, he founded an entire university whose lifetime achievement award to scholars of world renown saw as the first recipient Popper and a network of foundations whose name is inspired by the title of Popper's sociological work. I am talking about George Soros, his Open Society Foundations and also his most recent book (Soros, 2018). Whether he is much loved, admired, despised or hated is not relevant here. Here it is interesting to see how from the psycho-social context of Popperian classroom and his book on the open society we have arrived through the micro, meso and macro to the formation of a financial empire, social policy, educational policy of global impact. A similar event happened to the magisterium of Benjamin Graham (2005 but the original edition was published in 1949) from which the young student Warren Buffett drew inspiration for the strategy that led him to create the Berkshire Hathaway fund and his, today enormous, empire. Without Popper and Graham no Soros and Buffett, but without Soros and Buffett the works of Popper and Graham would probably have remained at most in micro reader circles. Soros and Buffett, though fleshand-blood individuals, have generated constructions of macro and global sense of impact within process dynamics but with a tipping point in which such constructions have become increasingly macro and, in a sense, have acquired autonomous life from their founders with a major caesura / work of system/environment selection and filtering. In these practical examples we meet for the first time and timidly the sociology of processes and the sociology of complex systems, emancipated from the old and dusty systemic sociology in AGIL style.

\section{Civilization, Globalization, Enlightenment and Explicitation}

The challenge of unifying sociology of processes and sociology of complex systems begins. This challenge will certainly not end in these pages, but it is precisely the investment strategy I would like to focus on for my small slice of Goudsblom's inheritance, knowing that I am not the main heir. Well, let us now imagine that today we have to design a master of universal history, in the sense of Goudsblom, recalling his decisive book on fire. What could be the first lecture? I propose: Civilization as Sociological Enlightenment. Let's see why. The fire was 
initially not even imagined by prehistoric men, then it was intuited and discovered with a minimum level of understanding and control and a very high level of risk, which humanity inevitably ran, otherwise we would not even be here. From the steam engine to the electric current, from oil to nuclear power, from more or less renewable energies to what today is at the most intuited but still little known and even less controlled, the process of civilization on fire, like every process of civilization is a growing process of understanding and control, a process however complex that requires rapid and strategic changes in problem setting and problem solving. A process, often tortuous and turbulent, of increasing knowledge, of enlightenment (in the sense of Luhmann, 1970-1995) and formalization, good manners are needed but not always enough. Peter Sloterdijk's thought, which I did not know at the time, today provides us with important elements to structurally couple sociology of processes and sociology of complex systems. "The true fundamental concept of modernity is not that of revolution but that of explicitation" (Sloterdijk, 2015: 78) and what is explicitation if not a process of enlightening civilization? This is linked to a concept that is well present in Elias and Goudsblom but, so to speak, in a hidden form: that of globalization which Slotedijik makes clear: "globalization is the rapid abrogation of the right to ignorance" (Sloterdijk, 2017: 38). In civilization understood as explicit globalization that leaves no respite to opinions that are not solidly argued and documented, the emotional perceptions of the media circus find less and less place and the delusion of omnipotence of politics (cf. Teubner, 2012: 54) and of public opinion that has an aesthetic/ethical/moral/political judgment on everything, especially on what it ignores. Political judgement is the mask behind which ignorance is concealed, the mask of bad faith. VI A Project in twelve lectures in memory of Goudsblom (Part 1) As mentioned above, the first lecture would be entitled "Civilization as Sociological Enlightenment". The following ones would deal with epistemology, theory, methodology, techniques and exemplary cases in a fluid and procedural way. The second would be entitled "For a Systemic-Procedural Sociological Epistemology" and would provide the concepts that really make the difference in the structural coupling between sociology of processes and sociology of complex systems including, for example:

1. The relationship between processuality and systemic functional director;

2. Process management of complexity;

3. The process as an effective implementation of the systemic programme.

Of course, these are just some of the concepts of a hypothetical lecture number two. The third lecture could focus on World Order Policy Modeling (De Nardis, 1991) in five key concepts that could trace a functional and procedural direction from the most basic to the most complex: a) institutional b) intergovernmental (interstate or international, as the case may be) c) federal d) trans- supranational e) neo-functionalist constructivism show how systemic processes are neither forms of vital-energetic spontaneity nor planning at the table of obscure and occult elites but something else that is precisely the object of this third lecture and that shows how the social history of humanity from the caves to today is in a book of 100-150 pages, to exaggerate. So far, therefore, I have outlined the first three lectures of an epistemological-theoretical nature, including the respective methodological apparatus: 
1. Civilization as Sociological Enlightenment,

2. For a systemic-procedural sociological epistemology,

3. World Order Policy Modelling.

The fourth lecture, more applicative, would offer students a moment of exemplification and practical explanation through the case of fire. In essence, the fourth lecture would be an upgrade of Goudsblom's book (1996) and Fire and Civilization is a title to which I cannot find a better alternative. The fifth lecture, equally illustrative, and practical, could focus on cosmopolitanism as an example of the complexification of the process of civilization showing the perspective errors of the worst kind, at least, reductionist of the worst science, politics and the world taken for granted of everyday life (1-Luckmann, 1966, Berger, 2011). Culture is a more rigid and divisive term of civilization and this is more so than the concept of cosmopolitanism already anticipated by Ernst Gombrich: "Ladies and gentlemen, the program you have in your hands is printed in alphabetical characters derived from the Phoenician, modified by the Greeks and Romans and Carolingian scribes in forms that were taken during the Italian Renaissance, the numbers came to us from ancient India through the Arabs, the paper on which the program is printed is a Chinese invention, arrived in the West in the eighth century [...] we are therefore heirs to many different civilizations" (1985: 15). Everything is interconnected and intertwined with everything, every attempt to subtract and separate is disastrous and leads to conflicts and wars as painful as senseless that in fact intertwine and interconnect everything even more (Remotti,1996). The sixth and last lecture of the first block could be about civilization and globalization of social and health policies to show how cosmopolitanism, globalization and centralization of policy modeling are heuristically viable for a knowledge based and science intensive society whose strategic priority is evident also in this pandemic scenario from COVID-19. This sixth lecture would also be an important practical declension of the third lecture. To sum up: Lecture 1. Civilization as Sociological Enlightenment Lecture 2. For a systemic-procedural sociological epistemology Lecture 3. World Order Policy Modeling Lecture 4. Fire and Civilization Lecture 5. Civilization, Cosmopolitanism and Complexity Lecture 6. Civilization and globalization of social and health policies. VII A Project in twelve lectures in memory of Goudsblom (Part 2). The seventh lecture would focus on nihilism (Goudsblom,1982) as an accelerator of civilization, the eighth lecture would focus on procedural methodology and systemic complexity of organizational design. A challenge to the mindset of many policy modellers and policy makers. The ninth would focus on Homo Sapiens. Sapiens as a contingent evolutionary form, i.e. on the scope and impact of processes on our species. A lecture particularly focused on technological developments that make a difference. The tenth lecture could be focused on complex systems, processes and global intangibles, i.e. on the forms of dematerialization carried out by the increasingly fast, global and powerful processes (digitization, finance, isotropic standardization of policies, pervasiveness of science in politics, for example in basing human rights on scientific knowledge such as equality and its opposite, racism, scientifically refuted by the inexistence of races within the human species). The eleventh lecture would be a classic of the Amsterdam School: sport as a global systemic 
process. The twelfth lecture would take the form of a round table with all eleven speakers from the previous lectures in order to update Goudsblom's work in a very accurate way by launching conferences, publications and projects to give continuity to the study of Goudsblom's work on a theoretical and applicative level within cosmopolitan strategies of hybridization with the works of other giants and with the main challenges of our time. VIII A conclusion, a beginning the best way to honor Goudsblom is for his earthly end to be a metaphysical Kantian beginning. This is the meaning, significance and gift of Goudsblom's work towards students and scholars of today, tomorrow and the future and of this still hypothetical "J. Goudsblom Graduate Program" in twelve lectures that I list here: Lecture 1. Civilisation as Sociological Enlightenment Lecture 2. For a Systemic-Procedural Sociological Epistemology Lecture 3. World Order Policy Modeling Lecture 4. Fire and Civilization Lecture 5. Civilization, Cosmopolitanism and Complexity Lecture 6. Civilization and globalization of social and health policies. Lecture 7. Nihilism Lecture 8. Process methodology and systemic complexity of organisational design. Lecture 9. The Homo Sapiens. Sapiens as a contingent evolutionary form Lecture 10. Complex systems, processes and global intangibles Lecture 11. Sport as a global systemic process Lecture 12. Round Table on Goudsblom's work All that is needed now is to identify the most fertile soils where this programme will hopefully be implemented in more and more editions.

\section{References}

Antonini. E. (2018), "Ad Amsterdam da Elias", Iannone, R. and Pitasi, A. (Eds.), Tra Amsterdam e Berlino, L'Harmattan, Torino, pp. 77-103.

Berger, P.L. and Luckmann, T. (1966), The social construction of reality, Penguin, London.

Berger, P.L. (2011), The adventures of an accidental sociologist, San Francisco, Prometheus.

Bortolini, M (2005), L'immunità necessaria, Booklet, Milano.

De Nardis, P. (1988), L'equivoco sistema, Franco Angeli, Milano.

De Nardis, P. (1991), Sociologia del limite, Meltemi, Roma.

De Swaan, A. (2015), The Killing Compartments, Yale University Press, Yale.

Elias, N. (2000), The Civilizing Process, Blackwell Publishing, Hoboken.

Elias, N. (1991), The Symbol Theory. London, Sage.

Gombrich, E. (1985), Custodi della memoria. Milano, Feltrinelli.

Goudsblom, J. (1982), Nichilismo e cultura. Bologna, Il Mulino.

Goudsblom, J. (1992), Fire and Civilization. London, Penguin.

Goudsblom, J. and. Mennell, S. (Eds) (1988a), The Norbert Eias Reader. Blackwell, Oxford.

Goudsblom, J. and. Mennell, S. (Eds) (1988b), Power and knowledge. Chicago, Chicago University Press.

Goudsblom, J and Pitasi, A. (1996), "Fuoco e civilizzazione", Sociologia Urbana e Rurale, Vol. 98 No. 49. 
Goudsblom, J. Jones E.L. and Mennell, S. (1989), Human History and Social Process. Exeter, University of Exeter Press.

Graham, B. (2005), The Intelligent Investor. New York, Harper.

Luhmann, N. (1995), Soziologische Aufklaerung. Opladen, Westdeutscher Verlag.

Luhmann, N. (1993), "Perché AGIL?” Teoria Sociologica, Vol. 1 No. 1.

Perulli, A. (Ed), 2011, "Eredità ed attualità di Norbert Elias", Cambio, Vol. 1 No. 1.

Pitasi, A. (2018), "Prologo: Geografia e spirito della teoria sociologica", Iannone, R. and Pitasi, A. (Eds.), Tra Amsterdam e Berlino, L’Harmattan, Torino, pp. 25-53.

Popper, K. (2012), The Open Society and its Enemies. London, Routledge.

Remotti, F. (1996), Contro l'identità. Laterza, Roma, Bari.

Sasaki, M., Goldstone J. A., Zimmermann, E., and Sandelson S.K. (Eds), Concise Encyclopedia of Comparative Sociology. Brill, Leiden.

Soros, G. (2018), Defense of Open Society. Public Affairs, New York.

Sloterdjik, P. (2017), Che cosa è successo nel XX secolo? Bollati Boringhieri, Torino.

Sloterdjik, P. (2015), Sfere III. Milano, Raffaello Cortina.

Tabboni, S. (1993), Norbert Elias. Il Mulino, Bologna.

Teubner, G. (2012), Nuovi conflitti costituzionali. Bruno Mondadori, Milano.

This paper was previously published in journal Cambio, Vol 9 No 19, 2020.

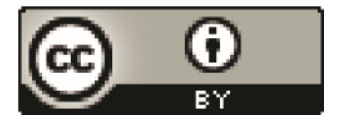

This article is distributed under the terms of the Creative Commons Attribution 4.0 License (https://creativecommons. org/licenses/by/4.0/) which permits any use, reproduction and distribution of the work without further permission provided the original work is attributed as specified on the WCSA Journal by World Complexity Science Academy (https://www.wcsaglobal.org/ethics-policy/). 